\title{
Puddling intensity for late-season sawah systems based on soil hydrophysical conditions and rice performance**
}

\author{
Sunday E. Obalum ${ }^{1,2}$, Yoshinori Watanabe ${ }^{1}$, Charles A. Igwe ${ }^{2}$, Martin E. Obi ${ }^{2}$, and Toshiyuki Wakatsuki ${ }^{1,3}$ \\ ${ }^{1}$ School of Agriculture, Kinki University, Nara 631-8505, Japan, \\ ${ }^{2}$ Department of Soil Science, University of Nigeria, Nsukka 410001, Nigeria \\ ${ }^{3}$ Faculty of Life and Environmental Sciences, Shimane University, Matsue, 690-8504, Japan
}

Received August 19, 2013; accepted February 18, 2014

\begin{abstract}
A b s t r a c t. Lowland sawah farmers often puddle to improve soil hydrophysical conditions for rice, but the puddling intensity beyond which no extra yield increases occur is unknown. Agronomic effects of six mechanical puddling intensities were assessed in three Nigerian inland-valley bottoms. All puddled plots, irrespective of intensity, produced similar effects at all three locations. At 10 days after transplanting, soil bulk density of all puddled plots represented mean decreases relative to control plots of about 22.4, 15.8 , and $31.7 \%$ at Akaeze, Adani, and Ejeti, respectively. Soil bulk density and moisture content upon saturation were similar during 40-120 days after transplanting. All puddled plots consistently showed taller plants and greater tillering than control plots only at Ejeti. Grain yields were similar among treatments in Akaeze and Adani (mean, 3.71 and $6.42 \mathrm{Mg} \mathrm{ha}^{-1}$, respectively), but one-pass puddling yielded numerically highest in both locations. At Ejeti, grain yields followed the trend for plant growth, with mean values of 4.36 and $1.81 \mathrm{Mg} \mathrm{ha}^{-1}$ for puddled and control plots, respectively. One-pass puddling may be sufficient for sawah rice grown late particularly in less humid environments.

K e y w o r d s: power-tiller passes, lowland sawah systems, water-controlling bunds, soil bulk density, rice grain yield
\end{abstract}

\section{INTRODUCTION}

The superiority of sawah systems over traditional rice (Oryza sativa L.) culture in West Africa is no longer debatable (Nwite et al., 2008; Obalum et al., 2012; Ofori et al., 2005). Sawah is a term adopted from Indonesia referring to an ecologically engineered lowland rice field, one that is pro-

\footnotetext{
*Corresponding author e-mail: ijewelle@yahoo.com

**This work was supported by the Ministry of Education, Culture, Sports, Science and Technology of the Japanese Government through a study fellowship to SEO and by the Japan Society for the Promotion of Science through its funding of the New Sawah Project in Nigeria, grant No. 19002001 (2007-2012).
}

perly demarcated using bunds, puddled, leveled and rowtransplanted to a high-yielding variety and, thereafter, kept under regulated flooding and routine fertilization. Lately, the research has been focused on reducing the cost of the system for enhanced acceptability to farmers. However, most of the studies in this regard concentrated on alternative fertilization strategies (Buri et al., 2004, 2008; Nwite et al., 2008, 2011). Under the sawah system, land preparation using a hand-operated power tiller is routinely done. This involves ploughing and puddling (wet tillage) to destroy soil aggregates, and sometimes leveling, thereby leaving soil hydrophysical conditions desired by the rice crop. Puddling with the power tiller is drudgery and costly in terms of time and fuel consumption. Moreover, interventions are often needed to facilitate the reformation of aggregates of puddled soils (Igwe et al., 2012). Puddling must therefore not exceed the intensity beyond which there are no significant increases in rice yields. This would help to sustain the cost-effectiveness of the sawah systems, and avert any adverse agronomic and environmental effects of such unguided puddling.

Improvements in soil hydrophysical conditions due to puddling are often viewed as contributing greatly to high yields of sawah rice (Obalum et al., 2012), but little is known about the optimum puddling intensity for lowland sawah systems. By contrast, poor water control and low soil fertility have been identified as the key constraints to high yields of rice under the sawah systems (Asubonteng et al., 2001). Indeed, several studies have demonstrated the positive contributions of the bunding aspect of sawah to field water control, soil fertility management, and rice yields (Becker 
and Johnson, 2001; Issaka et al., 2009; Toure et al., 2009). There is thus a need for data on the effects of puddling intensity (number of power tiller passes in a sawah plot) on lowland sawah performance, whereby all plots are bunded and maintained under similar soil water and fertility management throughout the growing seasons.

Soil bulk density (BD) is often used as a measure of puddling efficacy. Mousavi et al. (2009) noted that there are divergent views about puddling effects on soil physical conditions and rice yields. Generally, the finer the soil texture, the greater is the effect of puddling on soil physical condition (Kirchhof and So, 2005a; Mambani et al., 1990; Obalum et al., 2011). The puddling effect on rice yield also depends on soil texture, being evident in medium-textured soils (Mambani et al., 1990; Singh et al., 2001), but not in sandy-loam and fairly clayey soils (Bajpai and Tripathi, 2000; Lal, 1986; Mambani et al., 1990; Ogunremi et al., 1986). Similarly, puddling intensities usually influence rice yields in medium-textured soils, but not in sandy-loam soils and fairly clayey soils (Kirchhof and So, 2005b; Kukal and Aggarwal, 2003; Mohanty et al., 2004). Arora et al. (2006) showed in an Indian sandy-loam soil that, rather than puddling intensity, the irrigation regime had a greater impact on rice grain yield.

Therefore, the advice by Ogunremi et al. (1986) that tillage requirements for lowland rice be evaluated in terms of soil texture and field water conditions may benefit West African sawah research and development. Besides the underlying role of soil texture on the effects of puddling on lowland soils and rice, the data of Mambani et al. (1990) and Kirchhof et al. (2000) suggest that texturally similar soils could respond differently to puddling treatments if they occur in climatically diverse environments. The present study was hence conducted in three different inland-valley ecosystems in Nigeria to assess, in relative terms, the temporal variations in soil hydrophysical conditions and growth and yield of sawah rice grown with and without puddling at varying intensities. The objective was to establish the threshold beyond which further puddling will not increase rice yield.

\section{MATERIALS AND METHODS}

The study was conducted in lowlands occurring in three popular rice-growing environments in Nigeria, including Akaeze and Adani in the south and Ejeti in the north-central region in the 2009 (Akaeze and Ejeti) and 2010 (Adani and Ejeti) cropping seasons. In southern Akaeze and Adani occurring in the Derived Savanna zone, the geologic material is Shale formation with sand intrusions, whereas the Ejeti area in the Northern Guinea Savanna zone is underlain by Nupe sandstones. The lowlands in all the three study sites correspond to inland valleys. In the USDA classification system, the soils are sandy-loam Entisol at Akaeze and loam
Inceptisols at Adani and Ejeti (FDLAR, 1990). Some climatic features, as well as basic soil characteristics before the field studies, are shown (Table 1).

None of the selected sites was cultivated to rice in the last few years. The soils are all deep and hydromorphic and occur on a fairly level topography (slope rarely $>0.5 \%$ ). By August when the field study was started, the water table in all the three locations was fluctuating around the soil surface, as evident from topsoil saturation in the open fields.

In early August of each year, the experimental plot at each site was manually cleared and debris removed. The top-soil $(20 \mathrm{~cm})$ was randomly sampled for analyses before bunding to mark out 24 sub-plots into which the following six puddling treatments were replicated four times in a randomized complete block design (RCBD): one-pass puddling (1PP), two-pass puddling (2PP), three-pass puddling (3PP), four-pass puddling (4PP), four-pass puddling plus $(4 \mathrm{PP}+)$ surface dressing, and no power-tiller operations (debris removal only) which served as the control. Puddling was done using a two-wheel, 10.5-hp power tiller. The demarcating earthen bunds were approximately $0.5 \mathrm{~m}$ high. Inter-bund furrows (about $0.5 \mathrm{~m}$ wide) served as canals between every two blocks, and were used for drainage whenever the need arose, thus ensuring no interflow of water among sub-plots. While the sub-plot size was $8 \times 5 \mathrm{~m}$ at Akaeze and Adani, it was $12 \times 4 \mathrm{~m}$ at Ejeti.

The sub-plots were flooded before the puddling operation. 1PP entailed shallow puddling to a depth of about $8-10 \mathrm{~cm}$, whereas 2PP, 3PP, and 4PP entailed shallow puddling followed by additional puddling to a deeper layer of about 10 $12 \mathrm{~cm}$. The surface dressing in the 4PP + treatment, intended to achieve a zero-slope surface in the concerned sub-plots, was done using a wooden plank. However, this exercise entailed more of surface smoothening because of the fairly level topography of the sites.

The sub-plots were drained to the surface level a day after applying the puddling treatments, for ease of both transplanting and first soil sampling for BD. Then, 21-day-old seedlings of rice (var. WITA 4/FARO 52) were transplanted at 2 per hill at a spacing of $20 \times 20 \mathrm{~cm}$. This was done on August 8 and 15, 2009 at Akaeze and Ejeti, respectively and on August 15 and 20, 2010 at Adani and Ejeti, respectively. The sub-plots were maintained at negligible ponding for two weeks, at the end of which they received basal application of NPK $15-15-15$ at $400 \mathrm{~kg} \mathrm{ha}^{-1}$. Water was thereafter re-introduced into the sub-plots. Subsequent water management involved no supplemental irrigation from the canals; only draining of the sub-plots was done whenever ponding depth exceeded about $10 \mathrm{~cm}$. At maximum booting, urea was applied at $150 \mathrm{~kg} \mathrm{ha}^{-1}$ as top dressing. Weeds were manually removed wherever and whenever they sprouted and were due for removal during the growing seasons; no herbicides were used. Water management, which had been uniform for all treatments (including the control), was stopped two weeks before rice harvest. 
T a b I e 1. Some climatic features and basic characteristics of the top-soils $(0-20 \mathrm{~cm})$ in the inland-valleys

\begin{tabular}{|c|c|c|c|}
\hline Parameters & Akaeze & Adani & Ejeti \\
\hline \multicolumn{4}{|c|}{ Climatic variables } \\
\hline Mean annual rainfall amount (mm) & $1600^{1}$ & $1700^{1}$ & $1100^{2}$ \\
\hline Range of mean monthly min temperature $\left({ }^{\circ} \mathrm{C}\right)$ & $21-23$ & $20-24$ & $15-26$ \\
\hline Range of mean monthly max temperature $\left({ }^{\circ} \mathrm{C}\right)$ & $29-35$ & $28-36$ & $31-40$ \\
\hline Range of relative humidity (\%) & $55-90$ & $50-90$ & $43-87$ \\
\hline \multicolumn{4}{|c|}{ Soil properties } \\
\hline Coarse sand $\left(\mathrm{g} \mathrm{kg}^{-1}\right)$ & 300 & 26 & 96 \\
\hline Fine sand $\left(\mathrm{g} \mathrm{kg}^{-1}\right)$ & 404 & 378 & 208 \\
\hline Silt $\left(\mathrm{g} \mathrm{kg}^{-1}\right)$ & 200 & 400 & 460 \\
\hline Clay $\left(\mathrm{g} \mathrm{kg}^{-1}\right)$ & 96 & 196 & 236 \\
\hline Water-stable aggregates $(\%)$ & 55.0 & 12.2 & 24.0 \\
\hline Aggregate stability (\%) & 48.7 & 11.9 & 22.7 \\
\hline Mean-weight diameter (mm) & 0.53 & 0.23 & 0.27 \\
\hline Bulk density $\left(\mathrm{g} \mathrm{cm}^{-3}\right)$ & 1.46 & 1.23 & 1.35 \\
\hline Saturated hydraulic conductivity $\left(\mathrm{cm} \mathrm{h}^{-1}\right)$ & 5.25 & 1.63 & 1.25 \\
\hline Soil $\mathrm{pH}-\mathrm{H}_{2} \mathrm{O}$ & 4.9 & 4.9 & 4.6 \\
\hline Soil pH-KCl & 4.1 & 4.2 & 3.4 \\
\hline Soil organic carbon $\left(\mathrm{g} \mathrm{kg}^{-1}\right)$ & 12.8 & 16.8 & 12.5 \\
\hline Total nitrogen $\left(\mathrm{g} \mathrm{kg}^{-1}\right)$ & 0.7 & 0.7 & 1.0 \\
\hline Available $\mathrm{P}\left(\mathrm{mg} \mathrm{kg}^{-1}\right)$ & 4.66 & 7.46 & 16.5 \\
\hline Exchangeable potassium $\left(\mathrm{cmol}_{\mathrm{c}} \mathrm{kg}^{-1}\right)$ & 0.05 & 0.06 & 0.07 \\
\hline Exchangeable sodium $\left(\mathrm{cmol}_{\mathrm{c}} \mathrm{kg}^{-1}\right)$ & 0.17 & 0.13 & 0.33 \\
\hline Exchangeable calcium $\left(\mathrm{cmol}_{\mathrm{c}} \mathrm{kg}^{-1}\right)$ & 1.20 & 3.40 & 2.20 \\
\hline Exchangeable magnesium $\left(\mathrm{cmol}_{\mathrm{c}} \mathrm{kg}^{-1}\right)$ & 0.40 & 1.40 & 0.90 \\
\hline Exchangeable acidity $\left(\mathrm{cmol} \mathrm{kg}^{-1}\right)$ & 1.40 & 3.50 & 2.40 \\
\hline Cation exchange capacity $\left(\mathrm{cmol} \mathrm{kg}^{-1}\right)$ & 10.80 & 7.20 & 7.20 \\
\hline
\end{tabular}

${ }^{1}$ Bimodally distributed with peaks in July and October, ${ }^{2}$ unimodally distributed with a peak in August.

Soil samples were collected at 10, 40, 80, and 120 days after transplanting (DAT) from the topsoil $(10 \mathrm{~cm})$ layer of a central $4 \mathrm{~m}^{2}$ using $5 \times 5 \mathrm{~cm}$ cores. Sampling was done in triplicates; two were used to determine soil BD and the other to determine the moisture content both under ponded and non-ponded field conditions, which were simulated in the laboratory. To do this, about $20 \mathrm{~g}$ samples were placed inside two cylindrical vials $\left(\mathrm{V}_{\mathrm{p}}, \mathrm{V}_{\mathrm{n}}\right)$, saturated with de-ionized water, and shaken for a few seconds to achieve a level surface. More de-ionized water was added only to $V_{p}$ to have about $3 \mathrm{~cm}$ of water standing on the soil. The set-up was left in this condition to equilibrate for $24 \mathrm{~h}$. Then, water depth in $\mathrm{V}_{\mathrm{p}}$ was measured; any ponding water in $\mathrm{V}_{\mathrm{n}}$ was decanted. Using $\mathrm{V}_{\mathrm{p}}$ and $\mathrm{V}_{\mathrm{n}}$, the soil moisture content was calculated for ponded and non-ponded conditions, respectively, as follows:

$$
\begin{gathered}
M C_{p}=\left(M_{s w}-M_{p w}-M_{d s}\right) / M_{d s}, \\
M C_{n}=\left(M_{s w}-M_{d s}\right) / M_{d s},
\end{gathered}
$$

where: $M C_{p}$ and $M C_{n}$ - soil moisture content under ponded and non-ponded conditions, respectively, $M_{s w}$ - mass of wet soil and ponding water, $M_{p w}$ - mass of ponding water assumed to be numerically equal to its volume, $M_{d s}$ - mass of oven-dried soil. For both soil BD and moisture content analyses, oven-drying was achieved at $105^{\circ} \mathrm{C}$ for $24 \mathrm{~h}$.

From two centrally located portions, each having 50 plants $(10 \times 5$ rows $)$, data were also collected on plant height and the number of tillers at 10, 40, and 80 DAT. Harvesting took place at 120 DAT during December 5-7, 2009 and December 9-11, 2010 in all the three sites. Grain yield was 
assessed leaving out all 3-row border plants. After cutting the plants, grains were threshed, winnowed, and weights taken. Grain yield was reported at $14 \%$ moisture content.

The treatments were tested for differences by analysing the data using an ANOVA procedure appropriate for an RCBD experiment. For soil BD, comparison was also made across sampling dates for each puddling treatment using a general ANOVA procedure, with sampling dates as factors. Grain yields were also compared among locations in a similar manner. Treatments effects were considered significantly different at $p \leq 0.05$, followed by mean separation achieved by the LSD procedure. All analyses were performed using the software GENSTAT Discovery Edition 3 (VSN International, Hemel Hempstead, UK).

\section{RESULTS}

The responses of soil $\mathrm{BD}$ to the various puddling intensities are shown in Table 2. It was only at 10 DAT that puddled plots showed significantly $(\mathrm{p} \leq 0.05)$ lower values, compared to control plots. Notably, apart from Ejeti in the first year where soil $\mathrm{BD}$ was higher in $2 \mathrm{PP} / 3 \mathrm{PP}$ than in $4 \mathrm{PP} /$ $4 \mathrm{PP}+$, all puddled plots showed similar values at $10 \mathrm{DAT}$. The lowering of soil $\mathrm{BD}$ at $10 \mathrm{DAT}$ due to puddling was, however, not significant at Ejeti in the second year. On average, soil BD was decreased in puddled plots relative to control plots at 10 DAT by 22.4 and $15.8 \%$ at Akaeze and Adani, respectively. The corresponding extents of reduction at Ejeti were 31.7 and $11.9 \%$ in the first and second years, respectively. Although the differences at harvest (120 DAT) were not significant, values for soil BD were higher in all puddled plots compared to control plots, except for the second year data at Ejeti.

The data in Table 2 also show an overall trend of significant $(\mathrm{p} \leq 0.05)$ increases in soil $\mathrm{BD}$ in puddled plots with time, reaching the highest values during 40-80 DAT, after which the values dropped at harvest (120 DAT). In those puddled plots, however, BD values at harvest were consistently higher, compared to the values at 10 DAT. By contrast, apart from the second year trial at Ejeti, control plots showed lower soil BD at harvest than at 10 DAT.

The effect of wet tillage on the gravimetric moisture content of the sawah-managed soils upon saturation (under both ponded and non-ponded conditions) at 10,40, and 80 DAT are shown in Table 3. In general, puddled plots showed higher soil moisture status than control plots at $10 \mathrm{DAT}$ in all three locations; however, the differences were significant $(p \leq 0.05)$ only at Adani and Ejeti. Also, the soil moisture content was consistently higher under ponded than non-

T a b l e 2. Temporal changes in the soil bulk density $\left(\mathrm{g} \mathrm{cm}^{-3}\right)$ under the various treatments

\begin{tabular}{|c|c|c|c|c|c|c|c|c|c|c|}
\hline \multirow{2}{*}{ Treatment } & \multicolumn{10}{|c|}{ Days after transplanting } \\
\hline & 10 & 40 & 80 & 120 & $\mathrm{LSD}_{0.05}$ & 10 & 40 & 80 & 120 & $\mathrm{LSD}_{0.05}$ \\
\hline & \multicolumn{10}{|c|}{2009} \\
\hline & \multicolumn{4}{|c|}{ Akaeze } & \multicolumn{6}{|c|}{ Ejeti } \\
\hline $1 \mathrm{PP}$ & 1.20 & 1.49 & 1.59 & 1.44 & 0.10 & 0.97 & 1.23 & 1.38 & 1.36 & 0.24 \\
\hline $2 \mathrm{PP}$ & 1.27 & 1.56 & 1.61 & 1.50 & 0.17 & 1.04 & 1.25 & 1.31 & 1.23 & 0.18 \\
\hline $3 \mathrm{PP}$ & 1.23 & 1.53 & 1.67 & 1.40 & 0.14 & 1.05 & 1.22 & 1.26 & 1.32 & ns \\
\hline $4 \mathrm{PP}$ & 1.25 & 1.55 & 1.60 & 1.43 & 0.10 & 0.89 & 1.23 & 1.31 & 1.25 & 0.23 \\
\hline $4 \mathrm{PP}+$ & 1.22 & 1.55 & 1.73 & 1.46 & 0.11 & 0.90 & 1.30 & 1.22 & 1.28 & 0.24 \\
\hline Control* & 1.59 & 1.54 & 1.58 & 1.39 & 0.12 & 1.42 & 1.27 & 1.40 & 1.17 & ns \\
\hline \multirow[t]{3}{*}{$\mathrm{LSD}_{0.05}$} & 0.14 & ns & ns & ns & & 0.14 & ns & ns & ns & \\
\hline & \multicolumn{10}{|c|}{2010} \\
\hline & \multicolumn{4}{|c|}{ Adani } & \multicolumn{6}{|c|}{ Ejeti } \\
\hline $1 \mathrm{PP}$ & 1.15 & 1.55 & 1.51 & 1.48 & 0.14 & 1.02 & 1.66 & 1.76 & 1.61 & 0.18 \\
\hline $2 \mathrm{PP}$ & 1.15 & 1.45 & 1.51 & 1.40 & 0.14 & 1.06 & 1.75 & 1.81 & 1.65 & 0.38 \\
\hline $3 \mathrm{PP}$ & 1.15 & 1.59 & 1.45 & 1.45 & 0.16 & 1.07 & 1.95 & 1.83 & 1.66 & 0.27 \\
\hline $4 \mathrm{PP}$ & 1.16 & 1.42 & 1.50 & 1.32 & 0.16 & 1.06 & 1.85 & 1.75 & 1.75 & 0.22 \\
\hline $4 \mathrm{PP}+$ & 1.16 & 1.54 & 1.48 & 1.37 & 0.16 & 1.03 & 1.97 & 1.94 & 1.70 & 0.21 \\
\hline Control* & 1.37 & 1.44 & 1.38 & 1.32 & ns & 1.19 & 1.81 & 1.74 & 1.72 & 0.18 \\
\hline $\operatorname{LSD}_{0.05}$ & 0.08 & ns & ns & ns & & ns & ns & ns & ns & \\
\hline
\end{tabular}

$1 \mathrm{PP}$ - one-pass puddling, 2PP - two-pass puddling, 3PP - three-pass puddling, 4PP - four-pass puddling, 4PP + - four-pass puddling plus levelling, *debris removal only, ns - not significant. LSD - least significant difference. 
T a b l e 3. Temporal changes in the gravimetric moisture content of the soils following saturation under ponded (P) and non-ponded (N) conditions under the various treatments

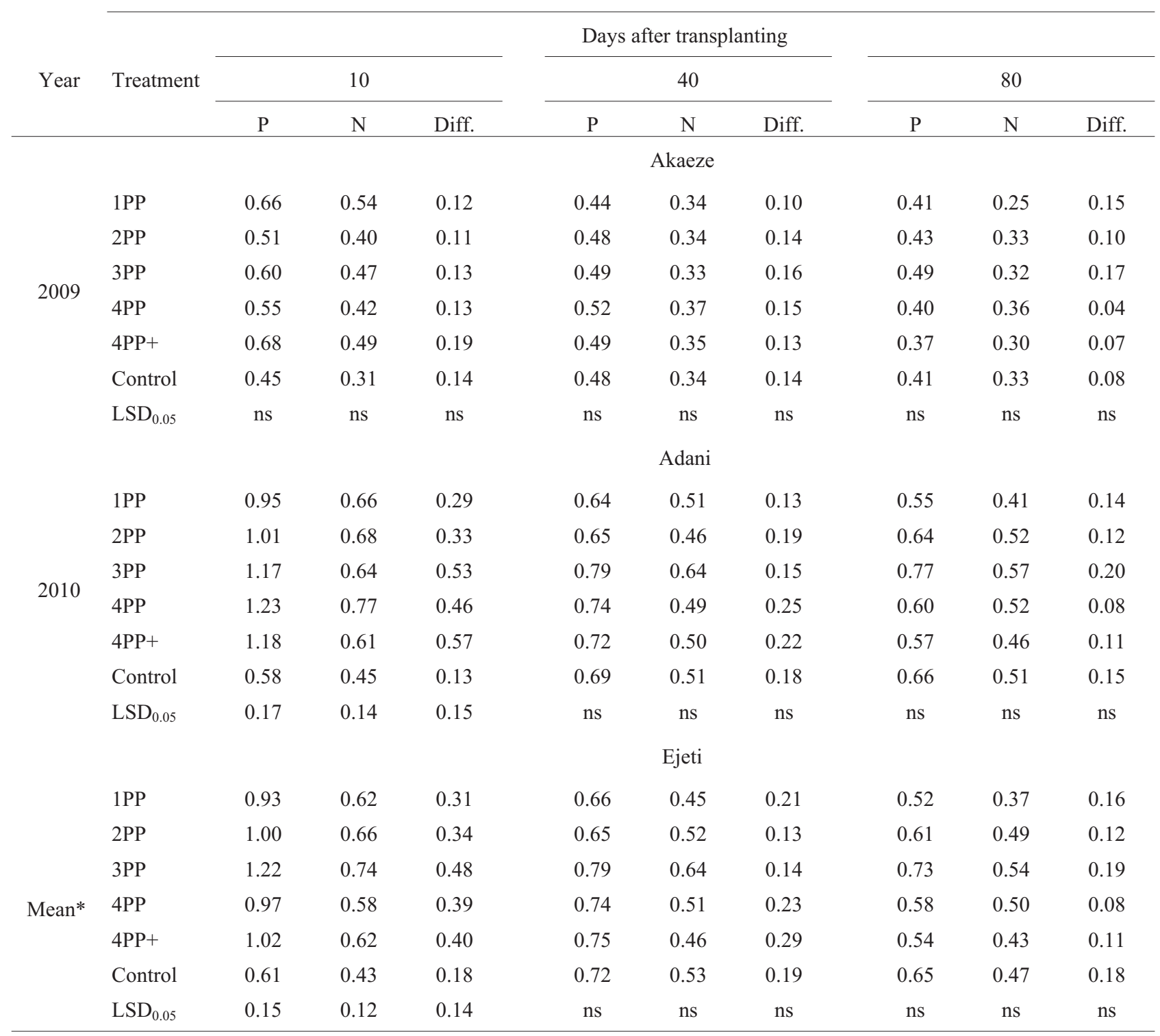

Explanations as in Table 2. *Mean for the two years (2009 and 2010).

ponded condition. Such differences were larger for puddled plots than for control plots at 10 DAT in Adani and Ejeti. On average, at $10 \mathrm{DAT}$, soil moisture content was higher in puddled plots than in control plots by about 33.3 and $49.7 \%$ at Akaeze, 91.0 and $49.3 \%$ at Adani, and 68.5 and $49.8 \%$ at Ejeti under ponded and non-ponded conditions, respectively. As with soil $\mathrm{BD}$, soil moisture content showed an overall tendency of decreasing in value with time in puddled treatments but not in the control plots, where instead the peak values were recorded at 40 DAT (Table 3).

The effect of puddling intensity on rice growth was assessed by the height of rice plants at three different times in the growing seasons (Table 4). In 2009, no differences in plant height existed among the treatments throughout the growing season at Akaeze; the reverse was the case at Ejeti, where all puddled plots outperformed the control. In 2010, some of the treatments showed taller rice plants than the control only at 40 DAT in Adani. The trend for 2009 was still maintained at Ejeti in 2010. Also, the effect of treatments on the number of rice tillers was generally not evident at Akaeze and Adani, whereas puddled plots generally showed more tillers than control plots at Ejeti (Table 5).

In the 2009 and 2010 growing seasons, all treatments showed comparable values of grain yield at Akaeze and Adani, respectively (Table 6). The trend in both locations, however, seems to be the highest yield in $1 \mathrm{PP}$, followed by 
T a b l e 4. Height of the rice plant $(\mathrm{cm})$ under the various treatments across the locations

\begin{tabular}{|c|c|c|c|c|c|c|c|}
\hline \multirow{2}{*}{ Year } & \multirow{2}{*}{ Treatment } & \multicolumn{6}{|c|}{ Days after transplanting } \\
\hline & & 40 & 80 & 120 & 40 & 80 & 120 \\
\hline \multirow{8}{*}{2009} & & \multicolumn{3}{|c|}{ Akaeze } & \multicolumn{3}{|c|}{ Ejeti } \\
\hline & $1 \mathrm{PP}$ & 53.8 & 67.1 & 78.7 & 66.2 & 83.1 & 119.8 \\
\hline & $2 \mathrm{PP}$ & 53.5 & 66.7 & 79.9 & 64.2 & 79.1 & 121.9 \\
\hline & 3PP & 53.6 & 68.9 & 84.4 & 70.2 & 84.1 & 124.6 \\
\hline & $4 \mathrm{PP}$ & 54.3 & 67.1 & 82.9 & 64.3 & 77.0 & 130.8 \\
\hline & $4 \mathrm{PP}+$ & 54.0 & 66.7 & 82.5 & 68.5 & 82.1 & 124.0 \\
\hline & Control & 53.1 & 69.3 & 77.9 & 54.4 & 71.8 & 108.1 \\
\hline & $\mathrm{LSD}_{0.05}$ & ns & ns & ns & 4.3 & 6.6 & 12.9 \\
\hline \multirow{8}{*}{2010} & \multicolumn{4}{|c|}{ Adani } & \multicolumn{3}{|c|}{ Ejeti } \\
\hline & $1 \mathrm{PP}$ & 84.5 & 119.1 & 127.9 & 69.1 & 97.9 & 112.8 \\
\hline & $2 \mathrm{PP}$ & 85.6 & 116.6 & 125.2 & 73.1 & 100.6 & 114.1 \\
\hline & $3 \mathrm{PP}$ & 89.5 & 120.1 & 128.9 & 67.4 & 97.2 & 110.3 \\
\hline & $4 \mathrm{PP}$ & 86.5 & 122.1 & 131.2 & 71.2 & 100.9 & 113.8 \\
\hline & $4 \mathrm{PP}+$ & 84.2 & 117.2 & 125.9 & 60.9 & 93.2 & 112.7 \\
\hline & Control & 80.0 & 119.1 & 124.9 & 50.6 & 82.4 & 100.4 \\
\hline & $\mathrm{LSD}_{0.05}$ & 5.5 & $\mathrm{~ns}$ & $\mathrm{~ns}$ & 11.0 & 7.6 & 3.7 \\
\hline
\end{tabular}

Explanations as in Table 2.

T a b l e 5. Number of tillers of the rice plant under the various treatments across the locations

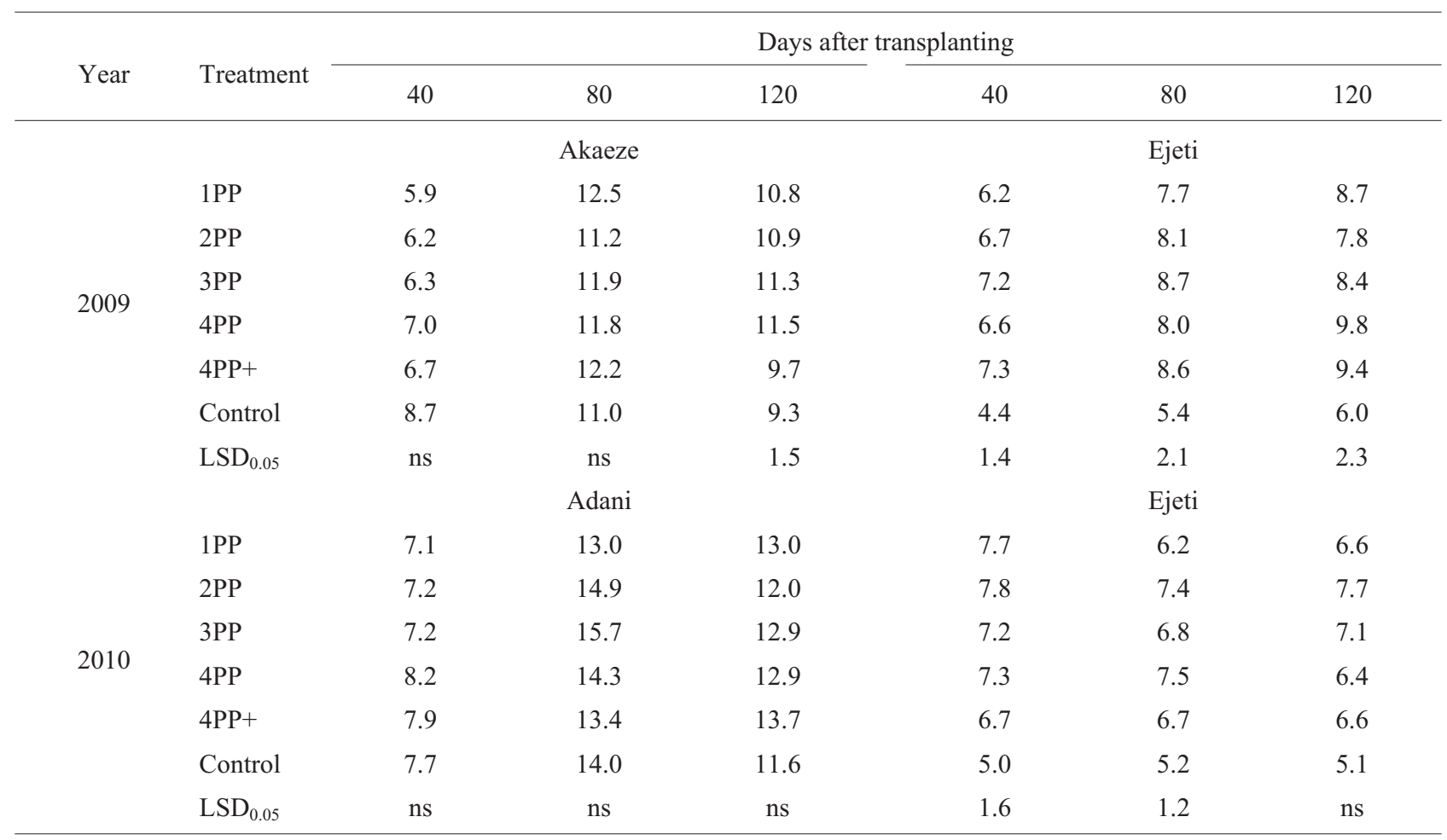

Explanations as in Table 2. 
T a b l e 6. Grain yield of rice $\left(\mathrm{Mg} \mathrm{ha}^{-1}\right)$ under the various treatments across the locations

\begin{tabular}{|c|c|c|c|c|c|c|}
\hline \multirow{2}{*}{ Treatment } & \multicolumn{3}{|c|}{2009} & \multicolumn{3}{|c|}{2010} \\
\hline & Akaeze & Ejeti & $\mathrm{LSD}_{0.05}$ & Adani & Ejeti & $\mathrm{LSD}_{0.05}$ \\
\hline $1 \mathrm{PP}$ & 4.06 & 4.25 & $\mathrm{~ns}$ & 7.38 & 4.41 & 2.58 \\
\hline $2 \mathrm{PP}$ & 3.50 & 4.25 & $\mathrm{~ns}$ & 5.75 & 4.98 & $\mathrm{~ns}$ \\
\hline $3 \mathrm{PP}$ & 3.62 & 4.35 & $\mathrm{~ns}$ & 5.53 & 3.94 & $\mathrm{~ns}$ \\
\hline $4 \mathrm{PP}$ & 3.75 & 4.28 & $\mathrm{~ns}$ & 7.00 & 4.14 & 2.01 \\
\hline $4 \mathrm{PP}+$ & 3.69 & 4.50 & ns & 7.00 & 4.48 & $\mathrm{~ns}$ \\
\hline Control & 3.62 & 1.68 & 0.71 & 5.88 & 1.93 & 2.79 \\
\hline $\operatorname{LSD}_{0.05}$ & $\mathrm{~ns}$ & 1.28 & & ns & 1.51 & \\
\hline
\end{tabular}

Explanations as in Table 2.

$4 \mathrm{PP} / 4 \mathrm{PP}+$, and then $2 \mathrm{PP} / 3 \mathrm{PP} /$ control. In both years of the study, however, grain yields under all puddled treatments at the Ejeti location were similar but the trends were largely inconsistent. All these puddled plots outyielded control plots (Table 6). The puddled plots represent, on average, 2.6 and 2.3 higher grain yields than the control plots in the first and second years, respectively. The extra task of levelling/ smoothening did not enhance grain yields in any of the locations.

In the first year, the differences in grain yield between Akaeze and Ejeti for each of the puddled treatments were not significant, though the values were consistently lower at Akaeze than Ejeti (Table 6). The control plots showed, however, significantly $(\mathrm{p} \leq 0.05)$ higher grain yield at Akaeze than Ejeti. In the second year, all treatments at Adani outyielded their counterparts at Ejeti, and some of these differences were significant (Table 6). On average, therefore, the overall productivity of the sites with respect to rice grain yield follows the order, Adani $>$ Ejeti $>$ Akaeze.

\section{DISCUSSION}

A reduction in soil $\mathrm{BD}$ due to puddling under field conditions is normal, but there may be no differences among puddled plots differing in puddling intensities immediately and up till 10 days after puddling (Mousavi et al., 2009). That the lowering of soil BD at 10 DAT was not significant at Ejeti in the second year suggests that the highest improvements in soil physical properties due to puddling may be expected in the first year of sawah establishment. The similarity in soil BD among the puddled plots in the mid-season (40-80 DAT) agrees with the findings of Behera et al. (2007) in a silty clay loam. The generally higher soil $\mathrm{BD}$ due to puddling (regardless of intensity) at harvest is a common observation, particularly in loam-textured soils (Bajpai and Tripathi, 2000; Lal, 1986; Nwite et al., 2010).
Considering the aggregate breakdown and gradual consolidation of the dispersed soil under a submerged condition, the initial increase in soil BD of puddled plots would be reasonable. This was not sustained until harvest when the soils were already drying, probably due to the dominance of non-swelling clay mineral and hence absence of shrinkage in the soils (Mohanty et al., 2004). The higher soil BD in puddled plots at harvest compared to the values at $10 \mathrm{DAT}$ was expected due to the sealing off soil pores by dispersed clay particles and/or by the compactive effect of the heavy machinery (Arora et al., 2006). The improvement in soil BD of puddled plots (after reaching peak values) and of control plots are generally attributable to alternate wetting/drying cycles in the sawah fields during the growing season (Bakti et al., 2010). These improvements in soil structure, coupled with the similarity among treatments at harvest, suggest that the deleterious effect of puddling on soil structure may not always persist after rice harvest.

Puddled plots maintained higher soil moisture status than control plots 10 DAT at Adani and Ejeti probably because of the finer soil texture (loam) in these locations compared to Akaeze with a sandy-loam texture. Similarly, the higher soil moisture content under ponded than non-ponded conditions being more pronounced in puddled plots than control plots at 10 DAT in Adani and Ejeti reflects clay dispersion and its high content in the topsoil after puddling (Kirchhof et al., 2005a; Lal, 1986). The results are thus attributed to the tendency of the soils to be still undergoing consolidation at $10 \mathrm{DAT}$. The overall tendency of progressive decrease in moisture content of puddled plots agrees with Behera et al. (2007). It appears that, as supported by the results for both soil BD and moisture contents in the present study, the beneficial effects of puddling on soil hydrophysical conditions are evident only early in the growing season.

The positive effect of puddling on rice height at Adani was restricted to the early phase of the growing cycle, as also reported by Kirchhof and So (2005b), due to the enhanced 
soil hydrophysical condition of puddled plots early in the season. This, however, was not evident in Akaeze probably because of the greater efficacy of puddling in soils with finer texture than their coarser counterparts, as regards creating and sustaining favourable soil hydrophysical conditions (Kirchhof and So, 2005a; Mambani et al., 1990).

The comparable yields under all treatments at Akaeze may be linked to its soil texture, for other authors reported similar results in other sandy-loam soils in southwestern Nigeria (Ogunremi et al., 1986) and northwestern India (Kukal and Aggarwal, 2003). Yields were similar too at Adani, despite the better early plant growth in puddled plots than control plots in this site. Huang et al. (2012) discussed in details some yield compensatory mechanisms of rice plants in non-puddled soils later in the growing season. The results for both Akaeze and Adani are also attributable to the ample rainfall in these sites and the associated uniform inundated conditions in the growing seasons (Arora et al., 2006; Kirchhof and So, 2005b), which was facilitated by the installed bunds and the fairly level topography of the sites. Becker and Johnson (2001) point out that field bunds can increase rice production in West Africa, while also possibly allowing a more efficient use of mineral fertilizers. Moreover, the high-intensity rainfall at Akaeze and Adani must have added to the dilapidatory effect of inundation on soil macropores in control plots (Sacco et al., 2012), thereby bringing them at par with puddled plots in terms of the percolation rate and ponding duration and, hence, yield.

In all three locations, levelling/smoothening did not enhance grain yields, as also found by Issaka et al. (2009) for lowland sawah systems in Ghana. The present results were probably due to the fairly level topography of the fields. Based on the underlying role of soil texture in the puddling effect on rice yield, we expected more distinct results in the loam-textured Adani and Ejeti soils (Kirchhof and So, 2005 b), more so as the soils are taxonomically similar. The fact that all puddled plots outyielded control plots only at Ejeti is thus an interesting one. We offer as partial explanation to these results the differences in biophysical environments of Adani and Ejeti (Mambani et al., 1990). The impact of such differences can be viewed from two perspectives.

One, these unstable, hydromorphic inland-valley soils of this study coalesce at the cessation of rains and remain hardened in the dry season, only to become re-wetted in the rainy season. The longer wet season at Adani than Ejeti means that the soil coalescence is usually less severe in the former in terms of intensity and duration. This also means that Adani soil had been under a re-wetted condition for a longer period compared to Ejeti soil at the start of the field study in August of each year. It is known that the longer such soils are under a waterlogged equilibrium condition, the greater the incidence of tilth-mellowing and aggregate destabilization needed to reduce percolation losses (Lennart et al., 2009). This is evident in the soil water-stable aggrega- tes and aggregate stability, each of whose value at Adani was about half that at Ejeti, despite the higher soil organic matter concentration in the former than the latter (Table 1). Thus, the need for puddling to smear soil aggregates in order to reduce the percolation rate and maintain inundation was greater in the relatively well-structured and permeable soil at Ejeti than the one at Adani.

Two, the high water table that existed at puddling was sustained at Adani for a much longer duration than at Ejeti, again due to the differences in the amount and distribution of rainfall between the two locations. This was the reason why, despite the initial reductions in soil BD, the effect of puddling on grain yield was not pronounced at Adani but at Ejeti (Bajpai and Tripathi, 2000; Kirchhof et al., 2000). The data presented by Olaleye et al. (2009) suggest that the drop in water table depth observed at Ejeti is a common phenomenon in valley bottoms in the area, especially after the rainfall peak in August. Beyond August itself when the field study was started in each year, rainfall in Ejeti for the rest of the growing season was about $280 \mathrm{~mm}$; in Adani, the corresponding value was about $550 \mathrm{~mm}$. The greater need to enhance water retention capacity of Ejeti soil later in the growing season was met in puddled plots but not in control plots, more so with its relatively high clay content. Puddling enhances water retention through compaction and clay dispersion (Bajpai and Tripathi, 2000; Kirchhof and So, 2005a). Therefore, the higher yields in puddled plots at Ejeti may be linked to the more favourable soil water condition in them and the associated efficient fertilizer use during the growing seasons, which was not the case in control plots (Toure et al., 2009).

Also, the uniform inundation of the plots at Adani had a suppressive effect on weed growth, such that virtually no differences in the intensity of weed infestation were observed between puddled and control plots during the growing seasons. By contrast, less weed infestation was observed in all puddled plots than control plots at Ejeti, and this must have contributed to the higher yields in the former than the latter (Becker and Johnson, 2001; Kirchhof et al., 2000; Singh et al., 2001). The results suggest, therefore, that a situation where power-tiller puddling is needed but not done under the sawah system, water control (using bunds) and fertilization may not bring about the desired high yield.

Since agronomic management techniques were similar in all sites, the yield differences among them were most likely due to soil-climate interactions, with conditions for rice production being most favourable at Adani with high rainfall and low-permeability soil (Kirchhof et al., 2000). The yields were higher at Ejeti which records lower rainfall compared to Akaeze, suggesting that the fairly low rainfall at Ejeti was compensated for by the higher moisture retention in the soil (Table 3 ) and the low permeability of the soil. The higher clay content and the initially higher soil available $\mathrm{P}$ at Ejeti than Akaeze would also partially explain the observation (Olaleye et al., 2010). 
Notably, the inundation status of puddled plots was rather similar in Adani and Ejeti, and so was to be a factor only for control plots. The reasons for the steadily higher yields at Adani-despite its lower soil available $\mathrm{P}$ at the start of the field study (Table 1) compared to Ejeti are not clear. Under non-sawah conditions of no water control measures in selected farmer-managed upland fields, Olaleye et al. (2010) reported no differences in rice grain yields across many locations in Nigeria. The present study sites are similar in rainfall (Akaeze and Adani), soil texture (Adani and Ejeti), and agro-management practices. We therefore infer from the yield data that lowland sawah systems provide the opportunity for detecting any differences in yield potential among rice-growing environments.

\section{CONCLUSIONS}

1. Puddling, regardless of intensity, decreases the soil bulk density while enhancing its moisture retention capacity, and these beneficial effects of puddling are evident particularly early in the season when they may also enhance rice growth.

2. Puddled soils may not show any post-harvest deterioration of structure in the short run.

3. One-pass puddling may be optional to enhance grain the yield of rice in sawah systems established after the first rainfall peak in more humid locations with bimodal rainfall pattern. In such locations, the option of one-pass puddling is encouraged to facilitate surface levelling (for uniform water distribution) and rice transplanting.

4. Even in less humid locations where puddling must be done, no agronomic benefits accrue from puddling beyond once. The practice of minimal puddling implies, among other benefits, less water requirement for puddling and this meets the greater need for water economy in such locations.

5. Rice yields of lowland sawah systems in texturally contrasting locations of a given rainfall zone respond more to even slight differences in soil texture than they do to puddling intensity.

6. The results of this study may be socio-economically important for sustainable intensification of rice using the sawah technology in West African inland-valley ecosystems.

\section{REFERENCES}

Arora V.K., Gajri P.R., and Uppal H.S., 2006. Puddling, irrigation, and transplanting-time effects on productivity of rice-wheat system on a sandy loam soil of Punjab, India. Soil Till. Res., 85, 212-220.

Asubonteng K.O., Kubota D., Hayashi K., Masunaga T., Wakatsuki T., and Andah E.I., 2001. Characterization and evaluation of inland valley watersheds for sustainable agricultural production: case study of semi-deciduous forest zone in the Ashanti Region of Ghana. Tropics, 10, 539-553.

Bajpai R.K. and Tripathi R.P., 2000. Evaluation of nonpuddling under shallow water tables and alternative tillage methods on soil and crop parameters in a rice-wheat system in Uttar Pradesh. Soil Till. Res., 55, 99-106.

Bakti L.A.A., Kirchhof G., and So H.B., 2010. Effect of wetting and drying on structural regeneration of puddled soil. In: Soil Solutions for a Changing World. Proc. 19th World Congr. Soil Science, August 1-6 2010, Brisbane, Australia.

Becker M. and Johnson D.E., 2001. Improved water control and crop management effects on lowland rice productivity in West Africa. Nutrient Cycling Agroecosys., 59, 119-127.

Behera B.K., Varshney B.P., and Swain S., 2007. Effect of puddling on physical properties of soil and rice yield. Agric. Mech. Asia, Africa Latin Am., 38, 23-28.

Buri M.M., Issaka R.N., and Wakatsuki T., 2008. Determining optimum rates of mineral fertilizers for economic rice grain yields under the "sawah" system in Ghana. West Afr. J. Appl. Ecol., 12, 19-31.

Buri M.M., Issaka R.N., Wakatsuki T., and Otoo E., 2004. Soil organic amendments and mineral fertilizers: options for sustainable lowland rice production in the forest agroecology of Ghana. Agric. Food Sci. J. Ghana, 3, 237-248.

FDALR, 1990. The reconnaissance soil survey of Nigeria. Soils Report. Federal Department of Agriculture and Land Resources Press, Abuja, Nigeria.

Huang M., Zou Y., Jiang P., Xia B., Feng Y., Cheng Z., and Mo Y., 2012. Effect of tillage on soil and crop properties of wetseeded flooded rice. Field Crops Res., 129, 28-38.

Igwe C.A., Nwite J.C., Agharanya K.U., Watanabe Y., Obalum S.E., Okebalama C.B., and Wakatsuki T., 2012. Aggregateassociated soil organic carbon and total nitrogen following amendment of puddled and sawah-managed rice soils in southeastern Nigeria. Archives Agron. Soil Sci., 59, 859-874.

Issaka R.N., Buri M.M., and Wakatsuki T., 2009. Effect of soil and water management practices on the growth and yield of rice in the forest agro-ecology of Ghana. J. Food Agric. Environ., 7, 214-218.

Kirchhof G., Priyono S., Utomo W.H., Adisarwanto T., Dacanay E.V., and So H.B., 2000. The effect of soil puddling on the soil physical properties and the growth of rice and post-rice crops. Soil Till. Res., 56, 37-50.

Kirchhof G. and So H.B., 2005a. Soil puddling for rice production under glasshouse condition-its quantification and effect on soil physical properties. Aust. J. Soil Res., 43, 617-622.

Kirchhof G. and So H.B., 2005b. Rice growth and post-rice mungbean in relation to two puddling intensities under glasshouse conditions. Aust. J. Soil Res., 43, 623-628.

Kukal S.S. and Aggarwal G.C., 2003. Puddling depth and intensity effects in rice-wheat system on a sandy loam soil II. Water use and crop performance. Soil Till. Res., 74, 37-45.

Lal R., 1986. Effects of 6 years of continuous no-till or puddling systems on soil properties and rice (Oryza sativa) yield of a loamy soil. Soil Till. Res., 8, 181-200.

Lennart B., Horn R., Duttman R., Gerke H.H., Tippkotter R., Eickhorst T., Janssen I., Janssen M., Ruth B., Sander T., Shi X., Sumfleth K., Taubner H., and Zhang B., 2009. Ecological safe management of terraced rice paddy landscapes. Soil Till. Res., 102, 179-192.

Mambani B., De Datta S.K., and Redulla C.A., 1990. Soil physical behaviour and crop responses to tillage in lowland rice soils of varying clay content. Plant Soil, 126, 227-235. 
Mohanty M., Painuli D.K., and Mandal K.G., 2004. Effect of puddling intensity on temporary variation in soil physical conditions and yield of rice (Oryza sativa L.) in a Vertisol of central India. Soil Till. Res., 76, 83-94.

Mousavi S.F., Yousefi-Moghadam S., Mostafazadeh-Fard B., Hemmat A., and Yazdani M.R., 2009. Effect of puddling intensity on physical properties of a silty clay soil under laboratory and field conditions. Paddy Water Environ, 7, 45-54.

Nwite J.C., Igwe C.A., and Wakatsuki T., 2008. Evaluation of sawah rice management system in an inland valley in southeastern Nigeria. I: Soil chemical properties and rice yield. Paddy Water Environ., 6, 299-307.

Nwite J.C., Igwe C.A., and Wakatsuki T., 2010. Evaluation of sawah rice management system in an inland valley in southeastern Nigeria II: changes in soil physical properties. J. Water Resour. Prot., 2, 609-618.

Nwite J.C., Obalum S.E., Igwe C.A., and Wakatsuki T., 2011. Properties and potential of selected ash sources for improving soil condition and sawah rice yields in a degraded inland valley in southeastern Nigeria. World J. Agric. Sci., 7, 304-310.

Obalum S.E., Nwite J.C., Oppong J., Igwe C.A., and Wakatsuki T., 2011. Comparative topsoil characteristics of sawah rice fields in selected inland valleys around Bida, northcentral Nigeria: textural, structural and hydrophysical properties. Paddy Water Environ., 9, 291-299.

Obalum S.E., Oppong J., Nwite J.C., Watanabe Y., Buri M.M., Igwe C.A., and Wakatsuki T., 2012. Long-term effects of lowland sawah system on soil physicochemical properties and rice yield in Ashanti Region of Ghana. Spanish J. Agric. Res., 10, 838-848.
Ofori J., Hisatomi Y., Kamidouzono A., Masunaga T., and Wakatsuki T., 2005. Performance of rice cultivars in various sawah ecosystems developed in inland valleys, Ashanti Region, Ghana. Soil Sci. Plant Nutr., 51, 469-476.

Ogunremi L.T., Lal R., and Babalola O., 1986. Effects of tillage methods and water regimes on soil properties and yield of lowland rice from a sandy loam soil in southwest Nigeria. Soil Till. Res., 6, 223-234.

Olaleye A.O., Ogunkunle A.O., Singh B.N., Akinbola G.E., and Obuh J., 2009. Morphology, organic carbon and dissolved nutrients in groundwater table in two benchmark wetlands sites in Nigeria. Agriculturae Conspectus Scientificus, 74, 31-37.

Olaleye A.O., Osiname O.A., Fashola R.O., Akinbola G.E., Ayanlaja S.A., Akinyemi J.O., and Obuh J., 2010. Interaction between grain yields of rice and environment (soil) in four agroecological zones in Nigeria. Comm. Soil Sci. Plant Anal., 41, 1220-1236.

Sacco D., Cremon C., Zavattaro L., and Grignani C., 2012. Seasonal variation of soil physical properties under different water managements in irrigated rice. Soil Till. Res., 118, 22-31.

Singh S., Sharma S.N., and Prasad R., 2001. The effect of seeding and tillage methods on productivity of rice-wheat cropping system. Soil Till. Res., 61, 125-131.

Toure A., Becker M., Johnson D.E., Kone B., Kossou D.K., and Kiepe P., 2009. Response of lowland rice to agronomic management under different hydrological regimes in an inland valley of Ivory Coast. Field Crops Res., 114, 304-310. 